\title{
Investigation of antibacterial effect of copper introduced titanium surface by electrochemical treatment against facultative anaerobic bacteria
}

\author{
Masaya SHIMABUKURO ${ }^{1,2}$, Yusuke TSUTSUMI 3,4 , Kosuke NOZAKI ${ }^{1}$, Peng CHEN ${ }^{3}$, Risa YAMADA ${ }^{1}$, Maki ASHIDA ${ }^{3}$, \\ Hisashi DOI ${ }^{3}$, Akiko NAGAI ${ }^{5}$ and Takao HANAWA ${ }^{3}$ \\ ${ }^{1}$ Graduate School of Medical and Dental Sciences, Tokyo Medical and Dental University, 1-5-45 Yushima, Bunkyo-ku, Tokyo 113-8549, Japan \\ ${ }^{2}$ Department of Biomaterials, Faculty of Dental Science, Kyushu University, 3-1-1 Maidashi, Higashi-ku, Fukuoka 812-8582, Japan \\ ${ }^{3}$ Institute of Biomaterials and Bioengineering, Tokyo Medical and Dental University, 2-3-10 Kanda-Surugadai, Chiyoda-ku, Tokyo 101-0062, Japan \\ ${ }^{4}$ Research Center for Structural Materials, National Institute for Materials Science (NIMS), 1-2-1 Sengen, Tsukuba, Ibaraki 305-0047, Japan \\ ${ }^{5}$ Department of Anatomy, School of Dentistry, Aichi Gakuin University, 1-100 Kusumoto-cho, Chikusa-ku, Nagoya 464-8650, Japan \\ Corresponding author, Yusuke TSUTSUMI; E-mail: TSUTSUMI.Yusuke@nims.go.jp
}

\begin{abstract}
This study investigated the efficacy of copper $(\mathrm{Cu})$ as an antibacterial element incorporated on titanium (Ti) surface by electrochemical treatment. $\mathrm{Cu}$ was incorporated onto Ti surface by micro-arc oxidation (MAO). A small amount of $\mathrm{Cu}$ was incorporated into the oxide layer and was found to be in oxidized states. Cu-incorporated samples exhibited no-harmful effect on the proliferation of osteoblastlike cells. Moreover, the difference in antibacterial property between fresh and incubated samples was evaluated using gram-positive and gram-negative facultative anaerobic bacteria. The specific antibacterial property of $\mathrm{Cu}$ incorporated into the Ti surface were confirmed. The antibacterial property prolonged upon immersion in physiological saline for 28 days. In other words, MAO-treated Ti containing $\mathrm{Cu}$ in this study is expected to achieve long-term antibacterial property in practical usage.
\end{abstract}

Keywords: Copper, Titanium, Antibacterial, Biofilm, Micro-arc oxidation

\section{INTRODUCTION}

Titanium (Ti) and its alloys are widely used as major implant materials owing to their excellent mechanical properties and biocompatibility. Recently, biomaterialassociated infections (BAI) caused due to the formation of a biofilm on biomaterial surface have been recognized as a major cause of failure in implant surgeries ${ }^{1-4)}$. The formation of biofilms is usually a result of bacterial adhesion, growth, and colony formation. Biofilms weaken the effect of antibiotic agents due to the variability of bacterial species and the barrier effect of extracellular polysaccharides ${ }^{5-9}$. Biofilm formation is the final phase of infection and it is almost impossible to eliminate the biofilm grown on the implanted device from the living body. The only solution is the removal of the contaminated device from the patient. This further surgery is necessary to avoid subsequent undesirable biological reactions such as infectious diseases. The prosthetic joint infection is divided into the early infection phase i.e. within 3 weeks after surgery, and the lateonset infection, which occurs later. Coventry reported that it takes around three to eight weeks after surgery until late-onset infection may become evident, and this period is considered as the incubation stag $\mathrm{e}^{10)}$. Thus, preventing bacterial invasion is necessary for assured implantation surgery, and imparting antibacterial properties to the implant materials is strongly desired. An ideal biomaterial surface with antibacterial properties will prevent bacterial adhesion at the initial

Color figures can be viewed in the online issue, which is available at J-STAGE.

Received Jun 14, 2019: Accepted Aug 28, 2019

doi:10.4012/dmj.2019-178 JOI JST.JSTAGE/dmj/2019-178 stages of infection and also inhibit subsequent bacterial growth at later stages.

Recent studies on antibacterial surfaces have employed various surface treatments with silver $(\mathrm{Ag})$ species $^{11-18)}$. Ag is known as a strong antibacterial element and its inhibitory effect on bacteria has been studied extensively. Many researchers have reported that Ag can strongly affect various kinds of fungal and bacterial strains including multidrug resistant strains of bacteria ${ }^{18-21)}$. However, excess Ag exerts toxic effects on the surrounding cells and tissues ${ }^{22-27)}$. Therefore, control of Ag release from implants is required for application of implant surface treatment. Copper $(\mathrm{Cu})$ is another important trace element in living organisms and is known to be one of an antibacterial element ${ }^{28-32)}$. The application of $\mathrm{Cu}$ for surface modification of implant devices may be utilized for achieving antibacterial properties similar to Ag.

Micro-arc oxidation (MAO) is an electrochemical surface treatment in a specific electrolyte under high voltage. The valve metal surface is covered by the unique porous structured oxide layer after the treatment. The resultant oxide layer formed by MAO treatment also consists of additional elements that are incorporated from the electrolyte solution. Therefore, many studies involving MAO as surface modification techniques for the purpose of improvement on the hard-tissue compatibility of $\mathrm{Ti}$ has been reported ${ }^{33-39)}$. Recently, several studies have been reported that MAO treated Ti with Ag shows good antibacterial property against both Staphylococcus aureus (S. aureus) and Escherichia coli (E. coli $)^{17,34)}$. Moreover, Cochis et al. reported that the MAO treated Ti 
with Ag showed effective antibacterial property against Acinetobacter baumannii ${ }^{18)}$. It has been proven that Ag-incorporated surfaces exhibit antibacterial effects against various bacteria.

On the other hand, studies based on the usage of $\mathrm{Cu}$ to attain antibacterial property by MAO treatment is limited. Yao et al. and Wu et al. reported that MAO treated $\mathrm{Ti}$ with $\mathrm{Cu}$ exhibits antibacterial effects against S. aureus and E. coli ${ }^{40,41)}$. Moreover, Zhu et al. reported that $\mathrm{Cu}$-incorporated $\mathrm{Ti}$ surface has no-harmful effects on calcification of osteoblasts ${ }^{42}$. However, the duration of antibacterial effect exerted by $\mathrm{Cu}$ incorporation is still unknown. The investigation of long-term antibacterial effect is important to combat late-onset infection, which develops more than 3 weeks after the implant surgery. Therefore, the present study aims to investigate the efficacy of $\mathrm{Cu}$ as an antibacterial element incorporated on Ti surface by MAO treatment. The difference in antibacterial property between fresh and four-week incubated samples was evaluated using gram-positive and gram-negative facultative anaerobic bacteria. In addition, the relationship between the presence of $\mathrm{Cu}$ on the treated surface, $\mathrm{Cu}$-ion release behavior, and biological effects on the bacteria and osteogenic cells were investigated. Surface characterization was also performed to examine the presence of $\mathrm{Cu}$, chemical states of $\mathrm{Cu}$, and release of $\mathrm{Cu}$-ions from the Ti surface. The long-term antibacterial effects associated with the biosafety of $\mathrm{Cu}$ related to osteogenic cells are discussed based on the surface analyses of the MAO-treated Ti surface.

\section{MATERIALS AND METHODS}

\section{Sample preparation}

Two types of Ti disks with diameters 8 and $25 \mathrm{~mm}$ were obtained by cutting rods of commercially pure grade 2 Ti. The disk surfaces were mechanically grinded using \#150, \#320, \#600, and \#800 grid SiC abrasive papers followed by ultrasonication using acetone and ethanol. The disks were then kept in an auto-dry desiccator, until further use. The Ti disk was fixed onto the polytetrafluoroethylene holder with an O-ring. The area in contact with the electrolyte was $39 \mathrm{~mm}^{2}(7.0$ $\mathrm{mm}$ in diameter) or $398 \mathrm{~mm}^{2}$ (22.5 $\mathrm{mm}$ in diameter). Details of the working electrode are described in the previous study ${ }^{43)}$. A type 304 stainless steel plate was used as a counter electrode. The base composition of the electrolyte for MAO treatment was $100 \mathrm{mM}$ calcium glycerophosphate and $150 \mathrm{mM}$ calcium acetate. In this study, $0,0.5,1.0$ and $2.5 \mathrm{mM} \mathrm{CuCl}_{2}$ were added to the base electrolyte. After pouring the electrolyte into the electrochemical cell, both electrodes were connected to a DC power supply (PL-650-0.1, Matsusada Precision, Shiga, Japan), and a positive voltage with a constant current density of $251 \mathrm{Am}^{-2}$, was applied for $10 \mathrm{~min}$. After MAO treatment, the sample surfaces were thoroughly washed in ultrapure water to remove the electrolyte solution remaining inside the porous oxide structure. In this study, a major part of the Ti disk was MAO-treated except an annular untreated area of $0.5 \mathrm{~mm}$ width from the edge. All the surface characterization described below were performed within the MAO-treated area.

\section{Incubation in a simulated body fluid}

The samples treated in the electrolyte with various concentrations of $\mathrm{Cu}$ were incubated in simulated body fluid for 28 days. Physiological saline ( $5 \mathrm{~mL}, 0.9 \% \mathrm{NaCl}$ ) was used, which is the simplest composition in simulated body fluid. The samples were fixed onto a polyethylene container to allow the release of $\mathrm{Cu}$ ions from the porous oxide layer. The experiment was performed at $310 \mathrm{~K}$ in a temperature-controlling chamber under roundlyshaking condition (100 rpm). The physiological saline was periodically exchanged every 7 days using the stored solution stock. After incubation, the samples were picked up from the solution to evaluate antibacterial property. In addition, the remaining solutions were used to investigate the amount of $\mathrm{Cu}$ ions released from the $\mathrm{Cu}$ incorporated surface.

Inductively-coupled plasma atomic emission spectroscopy (ICP-AES, ICPS-7000 ver. 2, Shimadzu, Kyoto, Japan) was performed to investigate the amount of $\mathrm{Cu}$ ions released from the $\mathrm{Cu}$-incorporated $\mathrm{Ti}$ sample surface.

\section{Surface characterization and $\mathrm{Cu}$ ion release evaluation} Scanning electron microscopy with energy dispersive X-ray spectrometry (SEM/EDS; S-3400NX, Hitachi HighTechnologies, Tokyo, Japan) was used to investigate the surface morphology of each sample. X-ray photoelectron spectroscopy (XPS; JPS-9010MC, JEOL, Tokyo, Japan) was performed using $\mathrm{Mg} \mathrm{K} \alpha \mathrm{X}$-ray source $(1,253.6 \mathrm{eV}, 10$ $\mathrm{kV}, 10 \mathrm{~mA})$. Instrument base pressure was $8 \times 10^{-10}$ Torr. All binding energies mentioned in this article are relative to Fermi level. The spectrometer was calibrated against $\mathrm{Au} 4 \mathrm{f}_{7 / 2}$ of pure gold, $\mathrm{Ag} 3 \mathrm{~d}_{5 / 2}$ of pure $\mathrm{Ag}$ and $\mathrm{Cu} 2 \mathrm{p}_{3 / 2}$ of pure $\mathrm{Cu}$. Spectra were obtained using an analysis area of $1 \mathrm{~mm} \varphi$ and $20 \mathrm{eV}$ pass energy. The detection angle was fixed at $90^{\circ}$. The binding energies were calibrated using that of $\mathrm{C}$ 1s photoelectron energy region peak derived from the contamination carbon $(285.0 \mathrm{eV})$. To estimate the integrated intensities of the peaks, the background was subtracted from the measured spectrum, according to Shirley's method ${ }^{44)}$. The chemical state of $\mathrm{Cu}$ inside the MAO-treated Ti surface were determined by modified auger parameter $\left(\alpha^{\prime}\right)$ on Wagner plot with those of typical $\mathrm{Cu}$ compounds. The $\alpha$ ' of each sample was calculated using equation (1),

$$
\alpha^{\prime}=E_{K}\left(\mathrm{Cu} \mathrm{L} \mathrm{VV}_{3}\right)+E_{B}\left(\mathrm{Cu} 2 \mathrm{p}_{3 / 2}\right)
$$

where $E_{K}$ shows kinetic energy of $\mathrm{Cu} \mathrm{L}_{3} \mathrm{VV}, E_{K}\left(\mathrm{Cu} \mathrm{L}_{3} \mathrm{VV}\right)$, and $E_{B}$ shows binding energy of $\mathrm{Cu} 2 \mathrm{p}_{3 / 2}, E_{B}\left(\mathrm{Cu} 2 \mathrm{p}_{3 / 2}\right)$. The quantitative analysis for determination of the sample compositions were performed according to the methods described in the previous study ${ }^{45}$. Empirical data $^{46,47)}$ and theoretically calculated data ${ }^{48)}$ were used for quantification. 


\section{Cell culture}

As described in our previous work ${ }^{49)}$, MC3T3-E1 cells (RIKEN BioResource Center, Tsukuba, Japan) were maintained in a cell culture medium, which was an alpha modification of Eagle's minimum essential medium ( $\alpha$-MEM, GIBCO, Grand island, CA, USA), supplemented with 10\% fetal bovine serum (FBS; GIBCO), $100 \mathrm{U}$ $\mathrm{mL}^{-1}$ penicillin, $100 \mathrm{mg} \mathrm{mL}^{-1}$ streptomycin, and $0.25 \mathrm{mg}$ $\mathrm{mL}^{-1}$ amphotericin B (GIBCO). In this study, cells were seeded on the sample at an approximate initial density of 10,000 cells $\mathrm{cm}^{-2}$. Then cells were incubated at $37^{\circ} \mathrm{C}$ in a fully humidified atmosphere containing $5 \% \mathrm{CO}_{2}$ in air. All of the samples were sterilized in advance in $70 \%$ ethanol for $20 \mathrm{~min}$ and thoroughly rinsed with deionized water before the test. The MAO-treated Ti without $\mathrm{Cu}(0$ $\mathrm{mM} \mathrm{Cu}$ ) was used as a control.

\section{Cellular proliferation}

Numbers of the cells attached to the sample surface after 1,2 , and 3 days after seeding were counted using Cell Counting Kit-8 (CCK-8, Dojindo Laboratories, Kumamoto, Japan). The attached cells on the tissueculturing treated polystyrene (TCPS) were harvested by treating with Trypsin/EDTA and then resuspended into the cell culture medium. Trypan blue (Trypan Blue Stain $0.4 \%$, GIBCO) was used to count the attached cells on TCPS. These cell suspensions were then diluted progressively and counted on a hemocytometer. On the other hand, these cell suspensions were also transferred into a 96 well microplate, in which the cell counting assay was performed. A reaction reagent was added to each sample, according to the manufacturer's instructions, and the reaction was continued for $4 \mathrm{~h}$, at $37^{\circ} \mathrm{C}$. The absorbance of the samples was measured at $450 \mathrm{~nm}$ using a microplate reader (ChroMate ${ }^{\circledR}$ Microplate Reader, Awareness Technology, Palm City, FL, USA) and a reference wavelength of $630 \mathrm{~nm}$ was used. Finally, the standard line calibrating the cell number and the light absorbance was obtained from the results.

\section{Cellular calcification}

The calcification behavior of MC3T3-E1 cells in each sample was evaluated by staining the calcified deposits by a color change reaction with alizarin red $\mathrm{S}$ reagent employing the following method. After removal of the culture medium, the samples along with the cells were rinsed thrice with phosphate-buffered saline. The cells were then fixed on the samples by immersing in $4 \%$ formalin for $1 \mathrm{~h}$ and rinsing thrice with ultra-pure water. Each sample was stained with $1 \%$ alizarin red S solution (adjusted to $\mathrm{pH} 4.2$ with ammonium hydroxide) at $25^{\circ} \mathrm{C}$ for $30 \mathrm{~min}$. After removing the alizarin red $\mathrm{S}$ solution, the samples were repeatedly rinsed with ultrapure water. An optical microscope (OLYMPUS SZX12, Olympus, Tokyo, Japan) was used to observe whole surface area of the samples.

\section{Antibacterial property evaluation}

The antibacterial property test was performed in accordance with ISO 22196:2007 method. To examine the antibacterial effect of MAO-treated Ti with various concentration of $\mathrm{Cu}, S$. aureus (NBRC122135) and E. coli (NBRC3972) were used in this study. The experiment was approved by Pathogenic Organisms Safety Management Committee of Tokyo Medical and Dental University (22012-025c). S. aureus and E. coli are used in antibacterial property tests as representative grampositive and gram-negative bacteria, respectively, as described in ISO 22196. S. aureus are gram-positive cocci frequently found in the nose, respiratory tract, and on the skin. However, E. coli is a gram-negative, rod-shaped bacterium, commonly found in the gut. Each strain was cultured according to its specific requirements. $S$. aureus and $E$. coli were cultured on tryptic soy broth (TryptoSoya Broth, Nissui, Tokyo, Japan) and LuriaBertani (LB) broth (LB-Medium, MP Biomedicals, Santa Ana, CA, USA), respectively, for $24 \mathrm{~h}$ at $37^{\circ} \mathrm{C}$, under ambient conditions. The optical densities of the bacterial suspensions were measured at $600 \mathrm{~nm}$ using an ultraviolet-visible (UV-vis) spectrometer (V-550, JASCO, Tokyo, Japan) to obtain the concentrations of $3-5 \times 10^{6}$ colony-forming units (CFU) $\mathrm{mL}^{-1}$. Prior to the antibacterial property tests, all samples were sterilized with $70 \%$ ethanol, washed with distilled water, and dried. Bacterial suspensions were dropped on all samples, which were subsequently covered with a sterilized plastic film and incubated at $37^{\circ} \mathrm{C}$ for $24 \mathrm{~h}(n=3)$. After collecting bacteria from the incubated samples, the obtained suspensions were 100-times diluted by physiological saline, pipetted onto nutrient agar plates, and incubated overnight at $37^{\circ} \mathrm{C}$. The number of viable bacteria was determined by counting the number of colonies formed on the petri plates.

\section{Statistical analysis}

The experimental data of the biological tests are presented as means \pm SD. The software, KaleidaGraph (Synergy Software, Reading, PA, USA) was used for statistical analysis. One-way analysis of variance was used to make multiple comparisons employing the Student-Newman-Keuls method to assess the data, and $p<0.05$ indicated statistical significance.

\section{RESULTS}

Surface characterization and $\mathrm{Cu}$ ion release evaluation Figure 1 shows SEM images of the MAO-treated $\mathrm{Ti}$ surfaces in the electrolyte with various $\mathrm{Cu}$ ion concentrations. The porous oxide layer formation was confirmed by all MAO-treatment conditions. The morphology of the oxide layer was almost same among the MAO treated samples with different $\mathrm{Cu}$ ion concentrations in the electrolyte. Figure 2 shows the XPS wide-scan spectra of the MAO-treated samples. Several peaks originated from $\mathrm{C} 1 \mathrm{~s}, \mathrm{O} 1 \mathrm{~s}, \mathrm{P} 2 \mathrm{p}, \mathrm{Ca} 2 \mathrm{p}$ and Ti $2 \mathrm{p}$ orbital binding energies were detected from all samples. The binding energies of the peaks of $\mathrm{P} 2 \mathrm{p}$ and $\mathrm{Ca} 2 \mathrm{p}_{3 / 2}$ were $133.7 \mathrm{eV}$ and $347.6 \mathrm{eV}$, respectively. It suggests that phosphorus and calcium in the oxide layer exist as a phosphate species and as divalent ions, respectively. The 


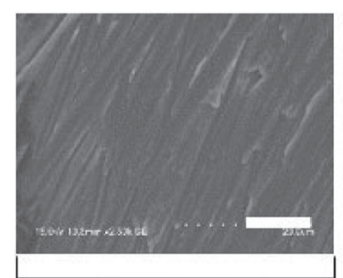

Untreated

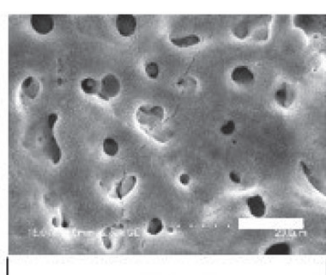

$\mathrm{Cu} O \mathrm{mM}$

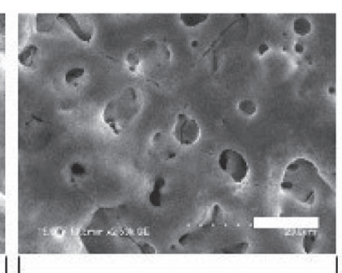

$\mathrm{Cu} 0.5 \mathrm{mM}$

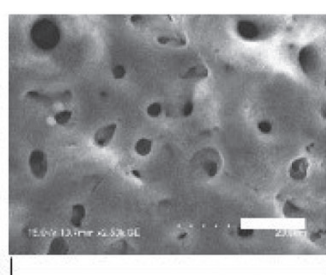

Cu $1.0 \mathrm{mM}$

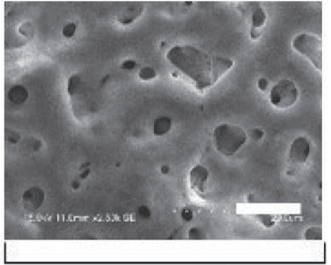

$\mathrm{Cu} 2.5 \mathrm{mM}$

Fig. 1 SEM images of each sample surface.

Scale bar is $10 \mathrm{~mm}$.

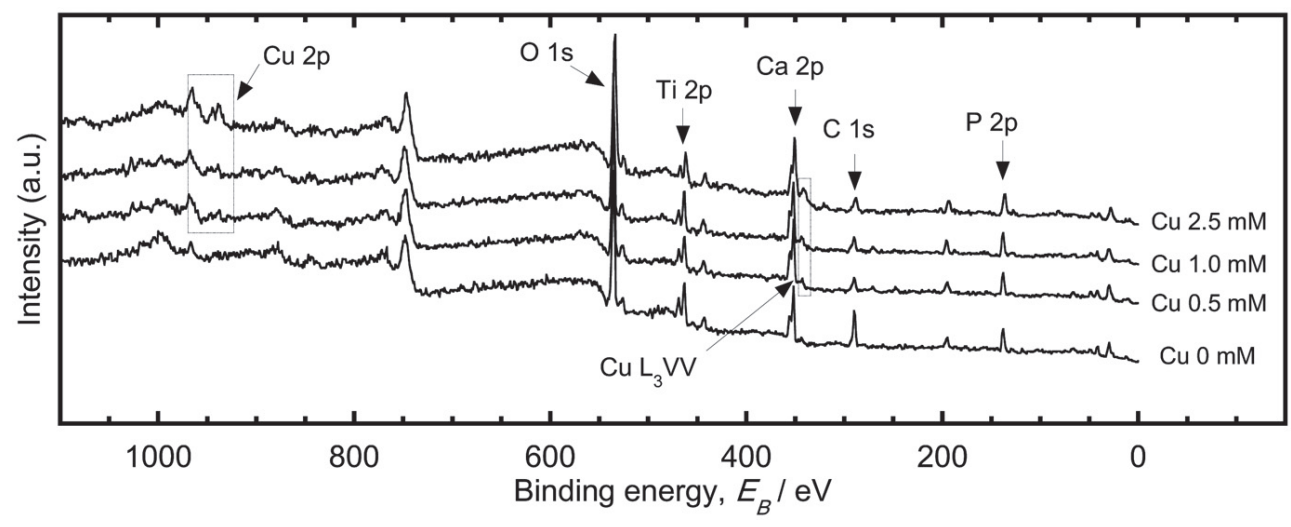

Fig. 2 XPS survey spectra of each sample.

binding energy of Ti $2 \mathrm{p}_{3 / 2}$ peak was $458.9 \mathrm{eV}$, indicating that $\mathrm{Ti}$ existed as $\mathrm{TiO}_{2}$. Moreover, $\mathrm{Cu} 2 \mathrm{p}$ photoelectron peaks and $\mathrm{Cu} \mathrm{L}_{3} \mathrm{VV}$ Auger electron peaks were detected in the samples treated with the electrolyte containing $\mathrm{Cu}$ ions. Figure 3 shows the Wagner plot of $\mathrm{Cu}$ in the oxide layer prepared by MAO treatment, based on $E_{B}$ of $\mathrm{Cu} 2 \mathrm{p}_{3 / 2}$ peaks and $E_{K}$ of $\mathrm{Cu} \mathrm{L}_{3} \mathrm{VV}$ peaks. The reference plots reported in other literature ${ }^{50-53)}$ using standard $\mathrm{Cu}$ chemical compounds are also shown in the Figure. The chemical states of the elements in different compounds are usually distinguished by reference to both $E_{B}$ and $\alpha$ ' values (parallel solid lines) in Wagner plot. The binding energy of $\mathrm{Cu}$ in the oxide layer was almost the same as that of $\mathrm{CuO}$. Moreover, the modified auger parameter values of $\mathrm{Cu}$ in the oxide layer were almost the same as that of $\mathrm{Cu}_{2} \mathrm{O}$. Therefore, the incorporated $\mathrm{Cu}$ element into the oxide layer is assumed to be in the complex of oxidized states.

Figure 4 shows the relative composition (atomic percentage) of $\mathrm{Cu}$ in the oxide layer, calculated by XPS quantitative analysis. It was confirmed that small amounts of $\mathrm{Cu}$ can be introduced into the surface oxide layer of $\mathrm{Ti}$ and its amount apparently increases with increase in the $\mathrm{Cu}$-ion concentration of the electrolyte for MAO treatment.

$\mathrm{Cu}$ in all tested solutions remained undetected, even though the detection limit of the machine was less than $0.1 \mathrm{ppm}$. In other words, extremely small amounts of $\mathrm{Cu}$, which were below the detection limit of ICP-AES, may be released from the porous oxide layers containing $\mathrm{Cu}$.

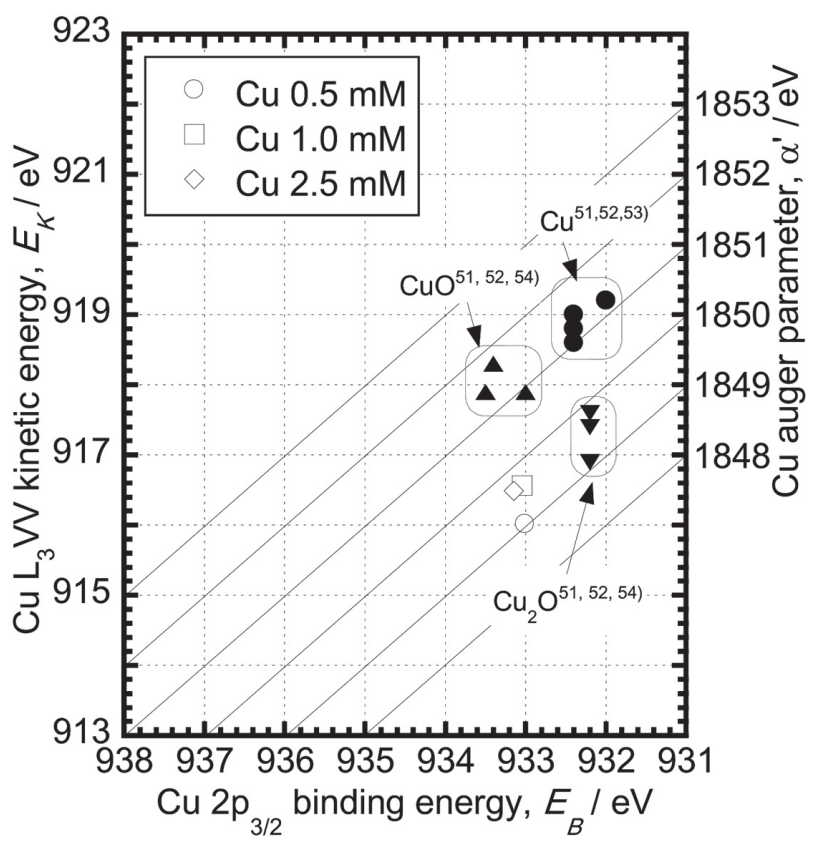

Fig. 3 The Wagner plot of $\mathrm{Cu}$ in the oxide layer based on $\mathrm{Cu} 2 \mathrm{p}_{3 / 2}$ peaks and $\mathrm{Cu} \mathrm{L}_{3} \mathrm{VV}$ Auger peaks.

Cellular proliferation

Figure 5 shows MC3T3-E1 cell growth on the samples for 1,2 , and 3 days after seeding. The living cell numbers 


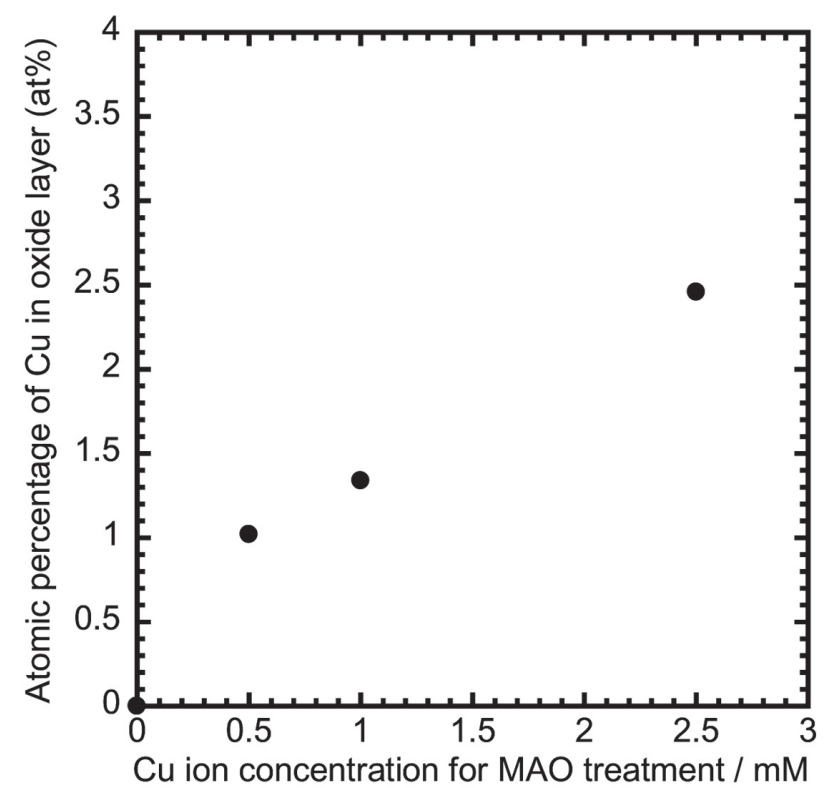

Fig. 4 Atomic percentage of $\mathrm{Cu}$ in the oxide layercalculated by quantitative analyzes of XPS spectra.

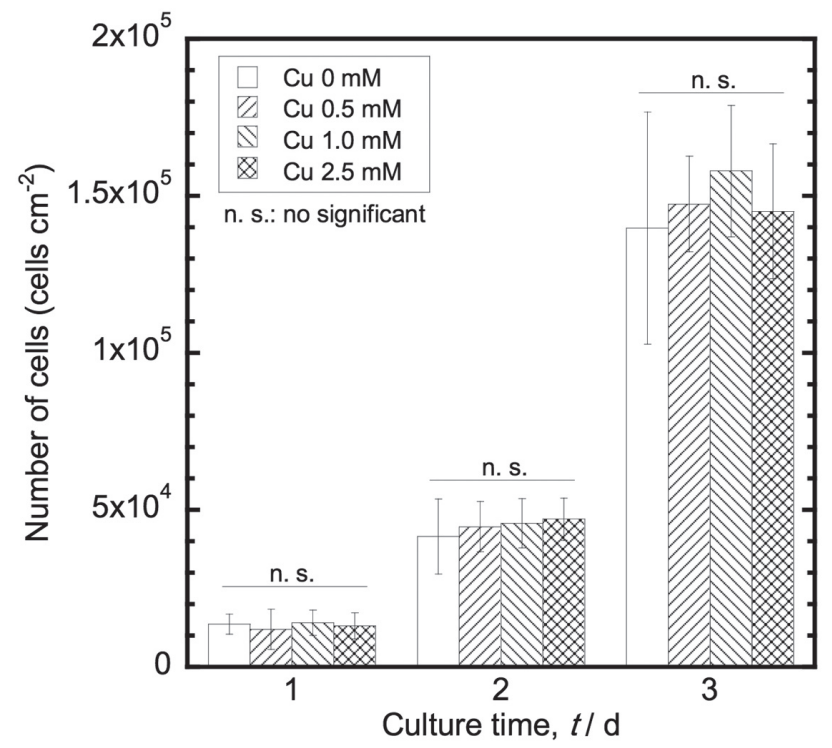

Fig. 5 Number of MC3T3-E1 cells on Ti MAO-treated in the electrolyte containing various concentration of $\mathrm{Cu}$ with culture time.

Data are shown as the mean \pm SD. n. s.: No significant difference $(p<0.05)$.

on the all samples tested in this study increased with increase in culture time. The growth rate of the cells showed no statistical differences among the samples with and without the $\mathrm{Cu}$ incorporation.

\section{Calcification}

Figure 6 shows the sample surface after the alizarin red $\mathrm{S}$ staining of calcified deposits in MC3T3-E1 cells

\begin{tabular}{|c|c|c|}
\hline \multirow{2}{*}{ Samples } & \multicolumn{2}{|c|}{ Culture time, $t / \mathrm{d}$} \\
\cline { 2 - 3 } & 14 & 21 \\
\hline $0-\mathrm{mM} \mathrm{Cu}$ & & \\
\hline $2.5-\mathrm{mM} \mathrm{Cu}$ & & \\
\hline
\end{tabular}

Fig. 6 Color scale stained by alizarin red $\mathrm{S}$ of calcified deposits by MC3T3-E1 cells on MAO-treated Ti with or without $\mathrm{Cu}$ cultured for 14 and 28 days. Scale bar represents $2 \mathrm{~mm}$.

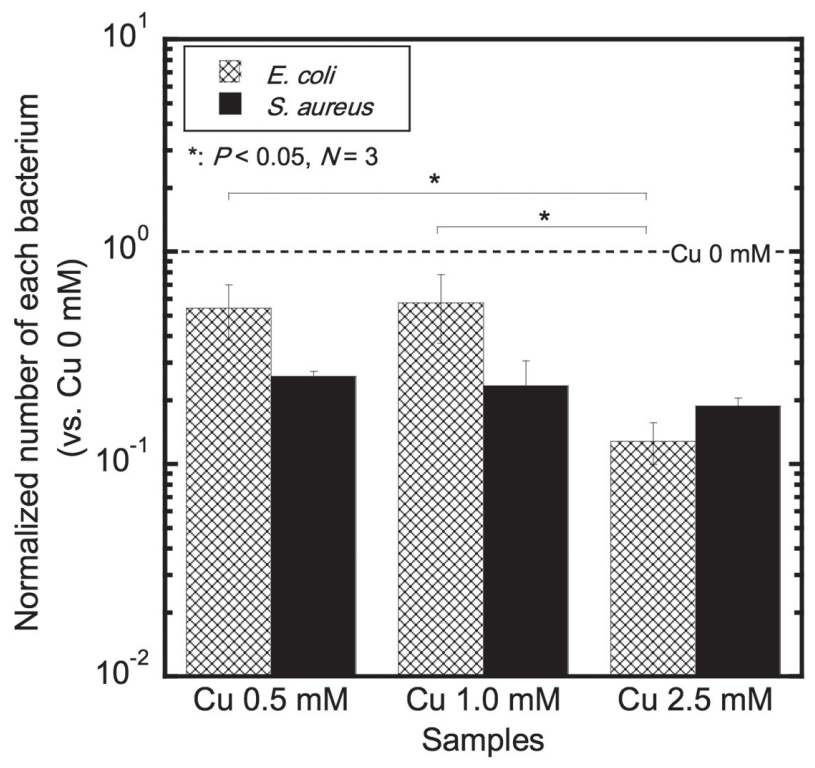

Fig. 7 Results of antibacterial evaluation using E. coli or S. aureus.

Data are shown as the mean \pm SD. *: Significant difference $(p<0.05)$.

after culturing for 14 and 28 days. The central part (7 $\mathrm{mm}$ in diameter) of the sample is the MAO-treated area covered with the oxide layer. The margins $(0.5 \mathrm{~mm})$ of the sample remains as untreated surface. The calcified cells were observed in all the samples. The whole MAOtreated area was evenly stained without any segregated area. There was no apparent difference between the MAO-treated samples with and without $\mathrm{Cu}$.

\section{Antibacterial property evaluation}

Figure 7 shows the antibacterial property evaluation using both $E$. coli and $S$. aureus. The vertical axis of the 

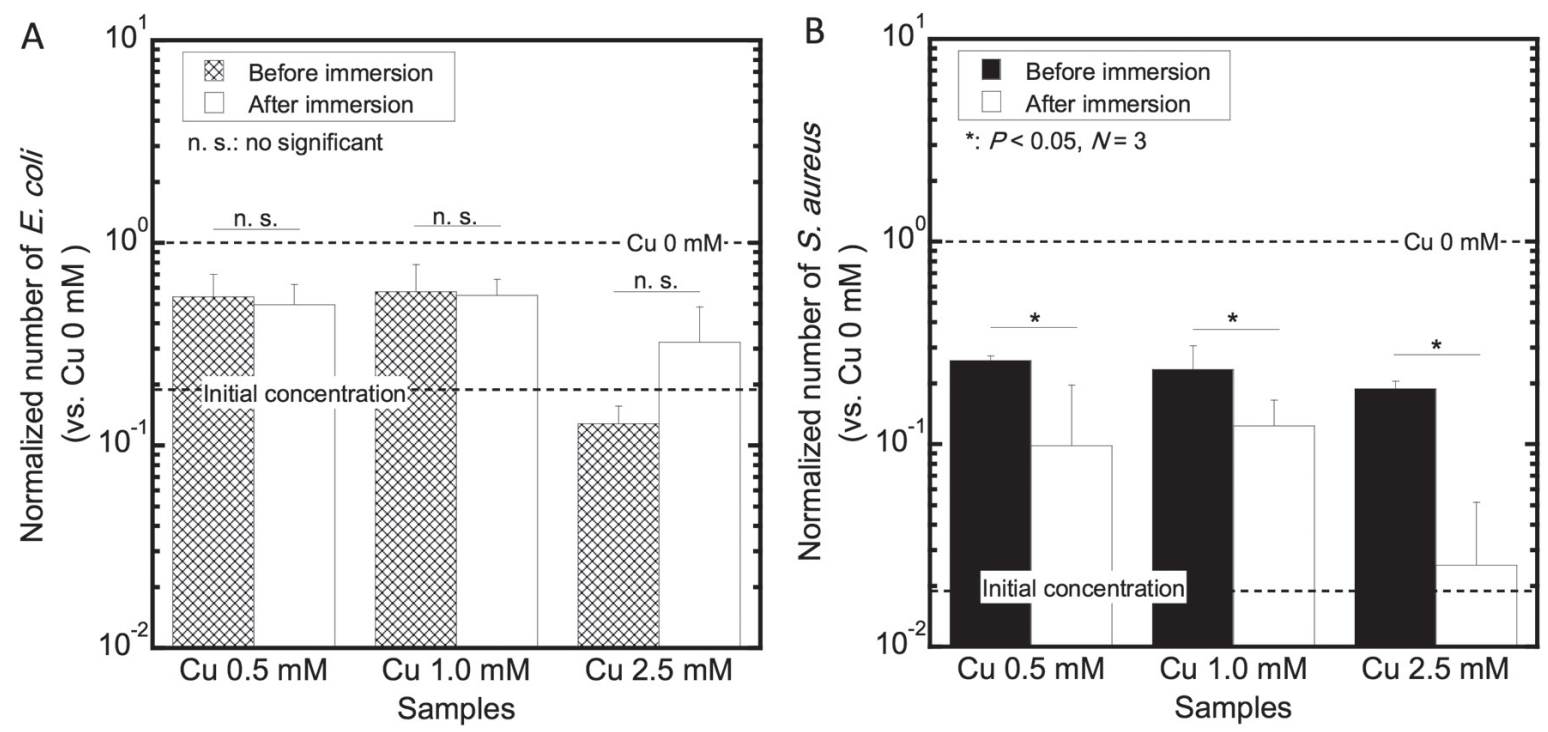

Fig. 8 The effect of sample aging by physiological saline in which samples were incubated for 28 days on the antibacterial property.

A and B show the number of E. coli (A) and (B) S. aureus on each sample. Data are shown as the mean \pm SD. *: Significant difference $(p<0.05)$. n. s.: No significant difference.

Figure represents the normalized bacterial number: The bacterial number on the tested sample is divided by that on the MAO-treated control sample without $\mathrm{Cu}$ in the electrolyte. The normalized bacterial number below 1 (broken line in the Figure) depicts that tested sample has antibacterial property and inhibits bacterial growth. The numbers of both $E$. coli and $S$. aureus on the samples containing $\mathrm{Cu}$ were smaller than those on the control samples without $\mathrm{Cu}$. The number of $E$. coli significantly decreased with increase in the $\mathrm{Cu}$ amount. Moreover, the growth of $S$. aureus was drastically inhibited on the $\mathrm{Cu}$-containing samples, even though they were prepared with the smallest $\mathrm{Cu}$-ion concentration.

Figure 8 shows the effect of sample aging by physiological saline in which samples were incubated for 28 days on the antibacterial property. The white colored bars in the Figure show the results of aged samples that were incubated in physiological saline for 28 days at 310 $\mathrm{K}$, simulating the living body environment. The number of $E$. coli shown in Fig. 8A were not significantly different between the fresh and the aged samples. On the other hand, the number of $S$. aureus shown in Fig. $8 \mathrm{~B}$ on the aged samples containing $\mathrm{Cu}$ was found to be significantly smaller than those on the fresh samples prepared with the same $\mathrm{Cu}$-concentration.

\section{DISCUSSION}

SEM observation confirmed that MAO treatment could be successfully performed in Cu-ion containing electrolytes, without changing the surface morphology of the Ti sample (Fig. 1). In addition, the presence of $\mathrm{Cu}$ in the MAO-treated samples was confirmed by the XPS wide scan spectra (Fig. 2). The atomic fraction of $\mathrm{Cu}$ inside the oxide layer, calculated by the XPS quantitative analysis using the narrow spectra $(\mathrm{Cu} 2 \mathrm{p})$, was found to increase with the increase in $\mathrm{Cu}$-ion concentration in the electrolyte for MAO treatment (Fig. 4). However, when the $\mathrm{Cu}$ ion concentration in the electrolyte exceeded $5 \mathrm{mM}$, the voltage applied during the treatment did not rise sufficiently and no porous oxide layer was formed on the Ti sample. It is believed that the anodic current was preferentially supplied by the electrolysis of water, which occurred on the surface of the sample because the oxide attained electro-conductivity. Thus, it was confirmed that $\mathrm{Cu}$ could be incorporated into the Ti surface oxide layer, to some extent, with the MAO treatment condition applied in this study. Moreover, the fraction of the incorporated $\mathrm{Cu}$ could be limited by adjusting the $\mathrm{Cu}$-ion concentration of the electrolyte. The behavior of $\mathrm{Cu}$ ion release in physiological saline was evaluated to simulate in vivo implantation period. The amount of $\mathrm{Cu}$ ions released from the sample surface could not be fully evaluated because the concentration of the $\mathrm{Cu}$ ions in the all tested solutions was lower than the detection limit of $10 \mathrm{ppb}$ (it corresponds to be $0.0126 \mu \mathrm{g} \mathrm{cm}^{-2}$ for this experimental condition). These results indicate that $\mathrm{Cu}$ ions were hardly released from the $\mathrm{Cu}$-incorporated porous oxide layer, unlike the $\mathrm{Ag}$ ions from the Ag-incorporated samples, which was previously reported by our group ${ }^{17)}$. The chemical state of the incorporated $\mathrm{Cu}$ atoms in the porous oxide layer formed by MAO treatment was found to be oxidized with complex state, as depicted by XPS Wagner plot analyses (Fig. 3). Both the oxides of $\mathrm{Cu}\left(\mathrm{Cu}_{2} \mathrm{O}\right.$ and $\left.\mathrm{CuO}\right)$ are known to be poorly soluble in neutral aqueous solution. Thus, the dissolution test results of undetectable $\mathrm{Cu}$ ions may be attributed to the poor solubility of $\mathrm{Cu}$ inside the oxide 
layer.

The number of living cells on the samples containing $\mathrm{Cu}$ inside the porous oxide layer was found to be the same as that on the sample without $\mathrm{Cu}$ (Fig. 5). It was clarified that MC3T3-E1 cells can proliferate on the $\mathrm{Cu}$-incorporated sample similar to the MAO-treated ones without $\mathrm{Cu}$. Moreover, the calcification behavior of the cells in MAO-treated samples was confirmed. There was no difference between the samples with and without $\mathrm{Cu}$ (Fig. 6). In other words, the $\mathrm{Cu}$-containing samples showed no harmful effects on the calcification of osteogenic cells even after long-term culture period (14 and 28 days). The amount of the incorporated $\mathrm{Cu}$ species into the porous oxide layer and the amount of $\mathrm{Cu}$ ions released were negligibly small for osteoblast-like cells. Therefore, all samples prepared in this study may be considered as biosafe for the surrounding osteogenic cells and tissues, if implanted in a living body.

The experimental results using anaerobic bacterial species clearly demonstrate the efficacy of the incorporated $\mathrm{Cu}$ on inhibiting their proliferation. Figure 7 shows the antibacterial effect of MAO-treated $\mathrm{Ti}$ samples using Cu-containing electrolyte against both $E$. coli and $S$. aureus. Moreover, the inhibition effect of incorporated $\mathrm{Cu}$ on $S$. aureus was stronger than that on E. coli. Generally, the minimum inhibitory concentration (MIC) of antibacterial agents is different for each bacterial species. The efficacy of $\mathrm{Cu}$ against $S$. aureus is higher than $E$. coli ${ }^{54)}$, therefore, the viability of $S$. aureus was lower than $E$. coli under similar exposure condition to $\mathrm{Cu}$ incorporated into the oxide layer. It is notable that the antibacterial effect of the incorporated $\mathrm{Cu}$, against $S$. aureus, was strengthened after incubation in physiological saline for 28 days. All samples showed smaller numbers of $S$. aureus after incubation treatment, as compared to the fresh samples (Fig. 8). Therefore, it was confirmed that the MAO-treated samples exhibited sustainable antibacterial property for a long period. Moreover, the specific effectiveness against $S$. aureus might be enhanced during the implantation period and this unique phenomenon is expected to be a solution for late-onset infection disease. On the other hand, $\mathrm{Cu}$-ion release was not observed in the dissolution test because the $\mathrm{Cu}$ concentrations in tested solutions were below detection limit of ICP-AES measurement. Therefore, it may be concluded that almost no $\mathrm{Cu}$ ion can dissolve into physiological environment from the MAO-treated Ti surface, when it is implanted to a living body. The antibacterial property of the sample prepared in this study can be explained by contact-killing effect on $\mathrm{Cu}$ species incorporated in the oxide layer rather than the nonspecific $\mathrm{Cu}$-ion release. The contact killing effect of $\mathrm{Cu}$ is introduced by specific $\mathrm{Cu}$ elusion behavior triggered by the bacterial contact, followed by the metabolic activities and it finally causes critical damage to the cell membrane ${ }^{55,56)}$. In other words, the $\mathrm{Cu}$ ion release might have been locally accelerated where the bacteria were attached. From the XPS analyses, the chemical state of the incorporated $\mathrm{Cu}$ was found to be of complex oxides (Fig. 3). The enhancement of the antibacterial property against $S$. aureus, after the incubation period, may be attributed to the transition of $\mathrm{Cu}$ oxides during the immersion in physiological saline. The osteoblast-like cell evaluation shows that the MAO-treated samples containing $\mathrm{Cu}$ exert no toxic effect on proliferation and calcification (Figs. 5 and 6). It was found that the porous oxide layers consist of not only Ti oxide but also incorporated $\mathrm{Ca}, \mathrm{P}$, and $\mathrm{Cu}$ (Fig. 2). Relatively large amounts of $\mathrm{Ca}$ and $\mathrm{P}$ in the MAO-treated Ti were also reported in other studies ${ }^{57,58)}$. $\mathrm{Ca}$ and $\mathrm{P}$ are the main components in living bone tissues as calcium-phosphate compounds. The presence of $\mathrm{Ca}$ and $\mathrm{P}$ in the porous oxide layer formed by MAO treatment enhances the activity of osteogenic cells. In our previous study, MAO-treated samples showed osteogenic cell compatibility which can accelerate the calcification process of MC3T-E1 cells, without any cytotoxicity ${ }^{17)}$. The $\mathrm{Cu}$-containing samples in this study may have similar biofunction as they contain $\mathrm{Ca}$ and $\mathrm{P}$ without preventing cell proliferation and calcification. In addition, the specific antibacterial property of the $\mathrm{Cu}$ which incorporated into Ti surface, was confirmed. The antibacterial activity prolonged upon immersion in physiological saline for 28 days. Thus, it may be concluded that MAO-treatment of Ti using $\mathrm{Cu}$ is suitable to attain long-term antibacterial property and osteogenic cell compatibility. This may be a promising technique for the development of novel dental materials and devices.

\section{CONCLUSION}

The Cu-incorporated porous oxide layer could be successfully prepared on Ti surface by MAO treatment in the electrolyte containing $\mathrm{CuCl}_{2}$. A small amount of $\mathrm{Cu}$ which presents complex oxide states was incorporated into the porous oxide layer. The amount of $\mathrm{Cu}$ ions released from the oxide layer into physiological saline was negligibly small and it was less than the detection limit of ICP-AES. Cu incorporated samples exhibited noharmful effect on the proliferation and calcification of osteoblast-like cells. On the other hand, the inhibition effect on the growth of anaerobic bacteria on the $\mathrm{Cu}$ incorporated samples was confirmed. The specific antibacterial property that prolonged and strengthened during immersion in physiological saline against $S$. aureus was also revealed by this study. Therefore, it could be concluded that the utilization of $\mathrm{Cu}$ with MAO treatment is expected to be promising technique for development of novel dental materials.

\section{ACKNOWLEDGMENTS}

This study was supported by the Research Center for Biomedical Engineering, Tokyo Medical and Dental University, Project "Creation of Life Innovation Materials for Interdisciplinary and International Researcher Development", and project "Cooperative project among medicine, dentistry, and engineering for medical innovation $\sim$ Construction of creative scientific research of the viable material via integration of biology 
and engineering " by Ministry of Education, Culture, Sports, Science and Engineering, Japan.

\section{REFERENCES}

1) Dibart S, Warbington M, Su MF, Skobe Z. In vitro evaluation of the implant-abutment bacterial seal: The locking taper system. Int J Oral Maxillofac Implants 2005; 20: 732-737.

2) Glauser R, Schupbach P, Gottlow J, Hammerle CH. Periimplant soft tissue barrier at experimental one-piece mini-implants with different surface topography in humans: A light-microscopic overview and histometric analysis. Clin Implant Dent Relat Res 2005; 7: S44-S51.

3) Tesmer M, Wallet S, Koutouzis T, Lundgren T. Bacterial colonization of the dental implant fixture-abutment interface: An in vitro study. J Periodontol 2009; 80: 1991-1997.

4) MacKintosh EE, Patel JD, Marchant RE, Anderson JM. Effects of biomaterial surface chemistry on the adhesion and biofilm formation of Staphylococcus epidermidis in vitro. $J$ Biomed Mater Res Part A 2006; 78A: 836-842.

5) Lindsay D, von Holy A. Bacterial biofilms within the clini-cal setting: What healthcare professionals should know. J Hosp Infect 2006; 64: 313-325.

6) Fux CA, Costerton JW, Stewart PS, Stoodley P. Survivalstrategies of infectious biofilms. Trends Microbiol 2005; 13: 34-40.

7) Stewart PS, Costerton JW. Antibiotic resistance of bacteriain biofilms. Lancet 2001; 358: 135-138

8) Hoiby N, Bjarnsholt T, Givskov M, Molin S, Ciofu O. Antibiotic resistance of bacterial biofilms. Int J Antimicrob Agents 2010; 35: $322-332$

9) Koo H, Allan RN, Howlin RP, Stoodley P, Hall-Stoodley L. Targeting microbial biofilms: current and prospective therapeutic strategies. Nat Rev Microbiol 2017; 15: 740-755.

10) Conventry MB. Treatment of infections occurring in total hip surgery. Orthop Clin North Am 1975; 6: 991-1003.

11) Gao A, Hang RQ, Huang $X B$, Zhao LZ, Zhang $X Y$, Wang L, et al. The effects of titania nanotubes with embedded silver oxide nanoparticles on bacteria and osteoblasts. Biomaterials 2014; 35: 4223-4235.

12) Necula BS, Fratila-Apachitei LE, Zaat SAJ, Apachitei I, Duszczyk J. In vitro antibacterial activity of porous $\mathrm{TiO}_{2}-\mathrm{Ag}$ composite layers against methicillin-resistant Staphylococcus aureus. Acta Biomater 2009; 5: 3573-3580.

13) Zhao LZ, Wang HR, Huo KF, Cui LY, Zhang WR, Ni HW, et al. Antibacterial nano-structured titania coating incorporated with silver nanoparticles. Biomaterials 2011; 32: 5706-5716.

14) Cao HL, Liu XY, Meng FH, Chu PK. Biological actions of silver nanoparticles embedded in titanium controlled by micro-galvanic effects. Biomaterials 2011; 32: 693-705.

15) Mei SL, Wang HY, Wang W, Tong LP, Pan HB, Ruan CS, et al. Antibacterial effects and biocompatibility of titanium surfaces with graded silver incorporation in titania nanotubes. Biomaterials 2014; 35: 4255-4265.

16) Gasqueres C, Schneider G, Nusko R, Maier G, Dingeldein E, Eliezer A. Innovative antibacterial coating by anodic spark deposition. Surf Coat Technol 2012; 206: 3410-3414.

17) Shimabukuro M, Tsutsumi Y, Yamada R, Ashida M, Chen $\mathrm{P}$, Doi $\mathrm{H}$, et al. Investigation of realizing both antibacterial property and osteogenic cell compatibility on titanium surface by simple electrochemical treatment. ACS Biomater Sci Eng 2019; 5: 5623-5630.

18) Cochis A, Azzimonti B, Della Valle C, De Giglio E, Bloise N, Visai L, et al. The effect of silver or gallium doped titanium against the multidrug resistant Acinetobacter baumannii. Biomaterials 2016; 80: 80-95.

19) Rai MK, Deshmukh SD, Ingle AP, Gade AK. Silver nanoparticles: the powerful nanoweapon against multidrugresistant bacteria. J Appl Microbiol 2012; 112: 841-852.
20) Lara HH, Ayala-Nunez NV, Turrent LDI, Padilla CR. Bactericidal effect of silver nanoparticles against multidrugresistant bacteria. World J Microbiol Biotechnol 2010; 26: 615-621.

21) Prakash P, Gnanaprakasam P, Emmanuel R, Arokiyaraj S, Saravanan M. Green synthesis of silver nanoparticles from leaf extract of Mimusops elengi, Linn. for enhanced antibacterial activity against multi drug resistant clinical isolates. Colloids Surf B Biointerfaces 2013; 108: 255-259.

22) Poon VKM, Burd A. In vitro cytotoxity of silver: implication for clinical wound care. Burns 2004; 30: 140-147.

23) Wataha JC, Lockwood PE, Schedle A. Effect of silver, copper, mercury, and nickel ions on cellular proliferation during extended, low-dose exposures. J Biomed Mater Res 2000; 52: 360-364.

24) Yamamoto A, Honma R, Sumita M. Cytotoxicity evaluation of 43 metal salts using murine fibroblasts and osteoblastic cells. J Biomed Mater Res 1998; 39: 331-340.

25) AshaRani PV, Mun GLK, Hande MP, Valiyaveettil S. Cytotoxicity and genotoxicity of silver nanoparticles in human cells. ACS Nano 2009; 3: 279-290.

26) Rosario F, Hoet P, Santos C, Oliveira H. Death and cell cycle progression are differently conditioned by the AgNP size in osteoblast-like cells. Toxicology 2016; 368: 103-115.

27) Contreras RG, Vilchis JRS, Sakagami H, Nakamura Y, Nakamura Y, Hibino Y, et al. Type of cell death induced by seven metals in cultured mouse osteoblastic cells. In Vivo 2010; 24: 507-512.

28) Hauert R. A review of modified DLC coatings for biological applications. Diam Relat Mater 2003; 12: 3-7.

29) Golcu A, Tumer M, Demirelli H, Wheatley RA. Cd(II) and $\mathrm{Cu}(\mathrm{II})$ complexes of polydentate Schiff base ligands: synthesis, characterization, properties and biological activity. Inorganica Chim Acta 2005; 358: 1785-1797.

30) Wu CT, Zhou YH, Xu MC, Han PP, Chen L, Chang J, et al. Copper-containing mesoporous bioactive glass scaffolds with multifunctional properties of angiogenesis capacity, osteostimulation and antibacterial activity. Biomaterials 2013; 34: 422-433.

31) Heidenau F, Mittelmeier W, Detsch R, Haenle M, Stenzel F, Ziegler G, et al. A novel antibacterial titania coating: Metal ion toxicity and in vitro surface colonization. J Mater Sci Mater Med 2005; 16: 883-888.

32) Raffi M, Mehrwan S, Bhatti TM, Akhter JI, Hameed A, Yawar $\mathrm{W}$, et al. Investigations into the antibacterial behavior of copper nanoparticles against Escherichia coli. Ann Microbiol 2010; 60: 75-80.

33) Ha JY, Tsutsumi Y, Doi H, Nomura N, Kim KH, Hanawa T. Enhancement of calcium phosphate formation on zirconium by micro-arc oxidation and chemical treatments. Surf Coat Technol 2011; 205: 4948-4955.

34) Song WH, Ryu HS, Hong SH. Antibacterial properties of $\mathrm{Ag}$ (or Pt)-containing calcium phosphate coating formed by micro-arc oxidation. J Biomed Mater Res A 2009; 88A: 246254.

35) Li LH, Kim HW, Kim YW, Kim HE, Heo SJ, Koak JY. Improved biological performance of Ti implants due to surface modification by micro-arc oxidation. Biomaterials 2004; 25: 2867-2875.

36) Li Y, Lee IS, Cui FZ, Choi SH. The biocompatibility of nanostructured calcium phosphate coated on micro-arc oxidized titanium. Biomaterials 2008; 29: 2025-2032.

37) Suh JY, Janga BC, Zhu X, Ong JL, Kim KH. Effect of hydrothermally treated anodic oxide films on osteoblast attachment and proliferation. Biomaterials 2003; 24: 347355.

38) Son WW, Zhu X, Shin HI, Ong JL, Kim KH. In vivo histological response to anodized and anodized/hydrothermally treated titanium implants. J Biomed Mater Res B Appl Biomater 
2003; 66B: 520-525.

39) Kim DY, Kim M, Kim HE, Koh YH, Kim HW, Jang JH. Formation of hydroxyapatite within porous $\mathrm{TiO}_{2}$ layer by micro-arc oxidation coupled with electrophoretic deposition. Acta Biomater 2009; 5: 2196-2205.

40) Yao XH, Zhang XY, Wu HB, Tian LH, Ma Y, Tang B. Microstructure and antibacterial properties of $\mathrm{Cu}$-doped $\mathrm{TiO}_{2}$ coating on titanium by micro-arc oxidation. Appl Surf Sci 2014; 292: 944-947.

41) Wu HB, Zhang XY, Geng ZH, Yin Y, Hang RQ, Huang XB, et al. Preparation, antibacterial effects and corrosion resistant of porous $\mathrm{Cu}-\mathrm{TiO}_{2}$ coatings. Appl Surf Sci 2014; 308: 43-49.

42) Zhu W, Zhang ZX, Gu BB, Sun JY, Zhu LX. Biological activity and antibacterial property of nano-structured $\mathrm{TiO}_{2}$ coating incorporated with $\mathrm{cu}$ prepared by micro-arc oxidation. J Mater Sci Technol 2013; 29: 237-244.

43) Tanaka Y, Kobayashi E, Hiromoto S, Asami K, Imai H, Hanawa T. Calcium phosphate formation on Ti by low-voltage electrolytic treatments. J Mater Sci Mater Med 2007; 18: 797 806.

44) Shirley DA. High-resolution X-ray photoemission spectrum of the valence bands of gold. Phys Rev B 1972; 5: 552-556.

45) Asami K, Hashimoto K, Shimodaira S. XPS determination of compositions of alloy surfaces and surface oxides on mechanically polished iron-chromium alloys. Corros Sci 1977; 17: 713-723.

46) Asami K, Chen SC, Habazaki H, Kawashima A, Hashimoto K. A photoelectrochemical and ESCA study of passivity of amorphous nickel-valve metal alloys. Corros Sci 1977; 31: 727-732.

47) Hashimoto K, Kasaya M, Asami K, Masumoto T. Electrochemical and XPS studies on corrosion behavior of amorphous Ni-Cr-P-B alloys. Corros Eng 1977; 26: 445452.

48) Scofield JH. Hartree-Slater subshell photoionization crosssections at 1254 and $1487 \mathrm{eV}$. J Electron Spectros Relat
Phenomena 1976; 8: 129-137.

49) Oya K, Tanaka Y, Moriyama Y, Yoshioka Y, Kimura T, Tsutsumi Y, et al. Differences in the bone differentiation properties of MC3T3-E1 cells on polished bulk and sputterdeposited titanium specimens. J Biomed Mater Res A 2010; 94: 611-618.

50) Schön G. ESCA studies of $\mathrm{Cu}, \mathrm{Cu}_{2} \mathrm{O}$ and $\mathrm{CuO}$. Surf Sci 1973; 35: 96-108.

51) Gaarenstroom SW, Winograd N. Initial and final state effects in the ESCA spectra of cadmium and silver oxides. J Chem Phys 1977; 67: 3500-3506.

52) Wagner CD, Riggs WM, Davis LE, Moulders JF. In: Mullen-berg GE, editor. Handbook of X-ray Photoelectron Spectroscopy. Physical electronics Division. Perkin-Elmer Corporation, Eden Prairie, Minnesota, 1979.

53) McIntyre NS, Rummery TE, Cook MG, Owen D. X-ray photoelectron spectroscopic study of the aqueous oxidation of monel-400. J Electrochem Soc 1976; 123: 1164-1170.

54) Ruparelia JP, Chatteriee AK, Duttagupta SP, Mukherji S. Strain specificity in antimicrobial activity of silver and copper nanoparticles. Acta Biomater 2008; 4: 707-716.

55) Hong R, Kang TY, Michels CA, Gadura N. Membrane lipid peroxidation in copper alloy-mediated contact killing of Escherichia coli. Appl Environ Microbiol 2012; 78: 17761784.

56) Grass G, Rensing C, Solioz M. Metallic copper as an antimicrobial surface. Appl Environ Microbiol 2011; 77: 15411547.

57) Tsutsumi $Y$, Niinomi M, Nakai M, Tsutsumi H, Doi H, Nomura N, et al. Micro-arc oxidation treatment to improve the hard-tissue compatibility of Ti-29Nb-13Ta-4.6Zr alloy. Appl Surf Sci 2012; 262: 34-38.

58) Tsutsumi Y, Niinomi M, Nakai M, Shimabukuro M, Ashida $\mathrm{M}$, Chen $\mathrm{P}$, et al. Electrochemical surface treatment of a beta-titanium alloy to realize an antibacterial property and bioactivity. Metals 2016; 6: 76 . 